\title{
PANDANGAN BURUH GENDONG DI YOGYAKARTA TERHADAP PERAN GANDA PEREMPUAN
}

\section{Sri Yulita Pramulia Panani}

Fakultas Filsafat, Universitas Gadjah Mada

Email: sriyulita@ugm.ac.id

\section{Aris Novita Rahayu}

Fakultas Filsafat, Universitas Gadjah Mada

\section{Wahyu Alga Ramadhan}

Fakultas Filsafat, Universitas Gadjah Mada

\section{Fitri Alfariz}

Fakultas Filsafat, Universitas Gadjah Mada

\section{Sartini}

Fakultas Filsafat, Universitas Gadjah Mada

\section{Abstrak}

Penelitian tentang paradigma peran ganda perempuan terutama pada komunitas marjinal, seperti buruh gendong di pasar, menarik untuk diungkap, karena sebagian perempuan masih dituntut untuk berperan dalam ranah domestik. Penelitian ini bertujuan untuk menganalisis peran ganda dalam pandangan buruh gendong di Yogyakarta. Penelitian ini menggunakan data kualitatif yang diperoleh melalui wawancara mendalam, observasi dan dokumentasi. Analisis terhadap data kualitatif dilakukan menggunakan metode filosofis, antara lain; induksi dan deduksi, komparasi, deskripsi dan refleksi. Hasil penelitian ini mengungkapkan bahwa buruh gendong memandang perempuan Jawa sebagai individu yang tidak hanya bersifat halus dan penurut tetapi juga tangguh, kuat, dan berani dalam mengambil sebuah tindakan. Buruh gendong memandang peran ganda yang dijalani sebagai bagian hidup perempuan yang harus dijalani dengan kerelaan dan ikhlas untuk memenuhi kebutuhan hidup. Konflik peran ganda dapat diatasi dengan sikap pandai mengatur waktu 
dan berbagi peran dalam pekerjaan rumah tangga. Dekonstruksi gender diperlihatkan buruh gendong pada pandangan bahwa perempuan juga dapat mencari uang dengan apa yang mereka miliki dan mampu kerjakan. Baik perempuan dan laki-laki memiliki kesempatan untuk bekerja sama dengan siapapun. Melalui hasil penelitian ini didapatkan pengetahuan baru bahwa peran ganda tidak selalu menjadi sesuatu yang memberatkan tetapi bagian dari kerelaan perempuan dalam membantu kebutuhan keluarga terutama pada kasus buruh gendong.

Kata kunci: Dekontruksi Gender, Perempuan Jawa, Peran Ganda

\section{Abstract}

A study about conception paradigm of double burden for women, particularly among marginal community, such as 'buruh gendong' (female manual labourers) is very important. It is particulalry because women traditionaly are stipulated in fullfiling domestic roles. This article based on qualitative research undertaken through detailed interviews, observations, and documentations. Analyzes were conducted using philosophical approaches including induction, deduction, comparation, description, and reflection. The results showed that Javanese women were not only refined in character and submissive, but also tough, strong, and decisive in making choices. They viewed double burden experiences as part of their lives, which should be ventured with willingness and sincerity. They tackled the conflict arising from the double burden by efficiency in time management and loadsharing in domestic chores. Gender deconstruction was shown as women who also can contribute economically by capitalizing their abilities. The viewed that women and men are all at the same status and have the same chances of working together side by side. This research revealed that woman's double burden was not always restriction for a woman to contribute to her family.

Keywords: Gender Deconstruction, Javanese Women, Double Burden

\section{PENDAHULUAN}

Perempuan Jawa dalam pemahaman budaya Jawa memperlihatkan posisi inferior bila dibandingkan dengan laki-laki. Merujuk pada pengertian asal kata wanita dalam budaya Jawa berarti wani ditata (berani diatur, ditata). Konsep ini mengandaikan bahwa wanita sebagai objek yang harus patuh pada subjek yang 
mengaturnya. Sebutan lain adalah perempuan sebagai konco wingking (teman di belakang), mengartikan posisi perempuan hanya berperan pada wilayah domestik dan tidak mempunyai akses untuk berperan ke publik. Wilayah domestik tersebut berkaitan dengan peran perempuan pada area dapur, kasur (kamar tidur) dan sumur, dengan tugas utama masak (memasak), macak (berdandan), manak (melahirkan) (Uyun, 2002). Hubungan laki-laki dan perempuan dalam perkawinan diungkapkan sebagai swarga nunut, neraka katut (ke surga menumpang, ke neraka pun terbawa). Posisi ini menggambarkan lemahnya perempuan/istri dalam perkawinan. Sebab, dalam ungkapan tersebut posisi perempuan berada sebagai 'objek' yang tergantung pada laki-laki.

Deskripsi perempuan Jawa dikenal sebagai seorang yang anggun, sopan bertingkah-laku, penurut, penyabar, sederhana, telaten, cekatan, bertutur lemah lembut, nrimo dan lain-lainya. Di sisi lain, seiring perkembangan zaman eksistensi perempuan mengalami perubahan. Hal tersebut ditandai dengan keberanian perempuan untuk tidak hanya berhenti berkecimpung pada area domestik tetapi melangkah masuk ke area publik dalam segala bidang. Bentuk keberanian perempuan untuk berperan aktif di luar area domestik salah satunya adalah berkarir/bekerja sesuai dengan kemampuan yang dimiliki. Perempuan yang bekerja ini, tidak hanya terbatas yang bekerja pada perusahaan negeri atau swasta, namun juga bekerja di sektor usaha kecil/menengah (UKM), seperti industri rumah tangga dan berjualan/berdagang di pasar.

Bentuk perempuan pekerja tidak terbatas pada apa yang telah disebutkan di atas, namun tidak terkecuali seperti kalangan buruh seperti komunitas buruh gendong di Yogyakarta. Buruh gendong adalah perempuan yang bekerja mengangkut barang, seperti sayuran dan barang-barang lain, dengan selendang di punggung mereka dengan berat muatan sesuai yang mereka mampu. Buruh gendong adalah salah satu contoh bagaimana perempuan Jawa, ketika dibenturkan dengan persoalan ekonomi mereka memiliki keberanian untuk keluar dari zona nyaman. Mendobrak disini diartikan sebagai sikap dan keberanian keluar dari batasan 
domestik dan melakukan pekerjaan apapun untuk memenuhi kebutuhan ekonomi keluarga. Alasan tersebut yang mendasari mereka memilih pekerjaan sebagai buruh gendong di pasar-pasar tradisional di Yogyakarta.

Kehidupan perempuan buruh gendong disebut sebagai endong-endong. Istilah tersebut hadir dalam dunia pekerja pasar. Keseharian endong-endong ini sibuk mencari nafkah dengan jalan menjual jasanya dengan mengorbankan tenaga tubuhnya. Perempuan-perempuan ini sebagian besar tidak memiliki keahlian khusus sehingga hanya memiliki kekuatan fisik yang dikapitalisasi dan dikonversi menjadi uang yang mereka terima sebagai upah harian. Buruh gendong dapat menggendong barang dengan beban $30 \mathrm{~kg}$ sampai $100 \mathrm{~kg}$. Kapasitas menggendong disesuaikan dengan kemampuan fisik masing-masing. Keadaan seperti itu membawa konsekuensi resiko dan fisik dan kesehatan.

Fenomena perempuan buruh gendong dapat dikatakan bahwa mereka tergolong perempuan yang belum memiliki keberuntungan dibandingkan perempuan yang bekerja pada sektor lain. Perempuan lain, seperti ibu rumah tangga, pegawai kantoran, guru dan lainnya, dianggap memiliki pekerjaan yang tergolong lebih enak dibandingkan dengan buruh gendong yang kesehariannya mengangkat beban yang berat (Kalimah, 2014).

Perempuan dalam istilah gender diartikan sebagai manusia yang lemah lembut, anggun, keibuan, emosional dan lain sebagainya. Baik di dunia timur maupun barat, perempuan digariskan untuk menjadi istri dan ibu. Sejalan dengan kehidupan ini, sifat yang dikenakan pada perempuan adalah makhluk yang emosional, pasif, lemah, dekoratif, tidak asertif dan tidak kompeten kecuali untuk tugas rumah tangga. Peran ganda adalah dua peran atau lebih yang dijalankan dalam waktu yang bersamaan; dalam hal ini peran yang dimaksud adalah peran seorang perempuan sebagai istri bagi suaminya, ibu bagi anak-anaknya, dan peran sebagai perempuan yang memiliki karir di luar rumah. Peran ganda ini dijalani bersamaan dengan peran tradisional kaum perempuan sebagai istri dan ibu dalam keluarga, seperti menjadi mitra suami 
dalam membina rumah tangga, menyediakan kebutuhan rumah tangga, serta mengasuh dan mendidik anak-anak (Fakih, 1996).

Penelitian mengenai peran ganda pada buruh gendong di Yogyakarta ini memiliki kebaharuan yang dimulai dari formulasi pertanyaan tentang korelasi konsep perempuan Jawa yang bergerak menunjukkan eksistensi memilih pekerjaan yang mereka bisa agar turut andil dalam pemenuhan ekonomi keluarga. Bukti ini diperkuat dengan keberadaan buruh gendong yang masih ada dari dulu hingga sekarang.

Penelitian ini dilakukan dengan pendekatan lapangan (field study) menggunakan data kualitatif yang diperoleh melalui wawancara mendalam, observasi dan dokumentasi. Pemilihan narasumber menggunakan snowball sampling, dilakukan secara acak dari berbagai umur dan dilakukan di tiga lokasi yaitu Pasar Giwangan, Pasar Beringharjo dan Pasar Kranggan. Analisis hasil data kualitatif yang diperoleh akan dianalisis menggunakan metode penelitian filsafat yaitu unsur-unsur metodis penelitian pandangan filosofis di lapangan antara lain; induksi dan deduksi, komparasi, deskripsi dan refleksi peneliti pribadi (Bakker \& Zubair, 1990). Tujuannya agar hasil penelitian ini memiliki ciri khas filsafat yang membedakan dengan bidang ilmu lain dan penelitian pendahulu dengan objek material perempuan buruh gendong.

Penelitian ini berusaha menganalisis dinamika buruh gendong sebagai perempuan Jawa dari kelompok marjinal yang berani memilih pekerjaan menggunakan otot yang identik dengan laki-laki, tetapi tidak meninggalkan perannya sebagai ibu dan isteri. Selain itu, penelitian ini berusaha menjawab bagaimana pandangan buruh gendong terhadap peran ganda yang mereka jalani, apakah mendatangkan masalah dalam rumah tangga mereka, dan bagaimana cara buruh gendong mengatasi konflik peran ganda tersebut. Penelitian ini dirasa penting ditelaah secara filosofis, untuk mengungkap apakah peran ganda selalu menimbulkan ketidakadilan bagi perempuan di berbagai profesi atau ada temuan berbeda pada kelompok etnis dan profesi tertentu. Penelitian ini 
membatasi pada subjek kelompok perempuan jawa yang berprofesi sebagai buruh gendong.

\section{PEMBAHASAN}

\section{Peran Ganda Perempuan}

Istilah peran ganda atau double burden yang dikaitkan dengan peran pada gender tertentu, terutama perempuan, dapat ditelusur dan dianggap pertama kali muncul bersamaan dengan menggiatnya revolusi industri (Pinchbeck, 1930). Masa revolusi industri ini ditandai dengan masifnya kegiatan produksi, baik secara volume maupun frekuensi kerja, untuk menghasilkan barang-barang yang digunakan untuk memenuhi permintaan pasar. Kegiatan produksi yang dimaksud terlihat di berbagai bidang/sektor, seperti industri pertambangan batu bara, pertanian, maupun domestik.

Revolusi industri membawa hal baik pada beberapa segi terhadap peningkatan kesejahteraan perempuan yang bekerja di bidang industri dan pabrik. Walaupun kondisi pabrik umumnya buruk, tetapi pekerjaan di pabrik ini dipandang lebih baik daripada bekerja pada kondisi industri yang bersifat domestik. Hal ini terjadi pada pekerja yang menjahit pakaian di rumah, diistilahkan sebagai buruh domestik, yang dibayar sebanyak jumlah potongan pakaian yang dihasilkannya. Perempuan pekerja yang bekerja di pabrik digolongkan lebih baik daripada buruh domestik karena terlepas dari pekerjaan yang sifatnya monoton dan kasar dengan standar upah yang tidak menentu karena hanya dibayar per volume produk hasil akhirnya. Selain itu, perempuan pekerja di pabrik memiliki beberapa kesempatan lain yang lebih bervariasi, misal bertemu kolega yang menawarkan pekerjaan lain, dan juga memiliki status sosial yang lebih baik (Pinchbeck, 1930).

Pada masa ini banyak orang melakukan pekerjaan di berbagai bidang industri, baik sebagai pegawai atau buruh biasa atau labourer. Pekerjaan ini menyerap tenaga dari kedua jenis gender sehingga tidak hanya dilakukan oleh laki-laki namun juga dilakukan oleh perempuan. Pekerja perempuan tidak hanya berasal 
dari perempuan yang belum menikah, tetapi juga berasal dari perempuan yang sudah berkeluarga dan memiliki anak. Secara umum perempuan-perempuan ini bekerja di industri tekstil, pertanian, dan tambang batu bara. Perempuan-perempuan ini juga bekerja pada pekerjaan lain yang diberi upah/gaji berdasarkan jumlah satuan produk yang dihasilkan, misal pekerja perempuan yang menjahit pakaian diupah dengan besaran sesuai kelipatan satu kodi pakaian yang dapat dihasilkan dalam sekali waktu bekerja (Reese, 2019).

Perempuan yang terjun sebagai pekerja pada saat Revolusi Industri mengalami beberapa kerugian (Reese, 2019), antara lain:

a. kondisi keselamatan dan kesehatan saat bekerja kurang terjamin. Pada saat Revolusi Industri, fokus kegiatan produksi adalah menghasilkan barang dalam jumlah besar. Untuk hal itu, penggunaan sumber daya dilakukan dengan masif dan eksploitatif, namun dengan pengeluaran atau imbalan ekonomi seminim mungkin. Kondisi minimal ini juga diterapkan pada kondisi tempat bekerja yang buruk dan tidak menjaga sanitasi, serta kurang memperhatikan keselamatan pekerja;

b. edukasi menjadi kurang terpikirkan karena beban kerja yang besar sehingga memakan porsi lebih banyak dari waktu 24 jam;

c. terdapat kesenjangan upah/gaji dibandingkan dengan buruh laki-laki;

d. terdapat unsur eksploitasi terhadap buruh perempuan yang berusia muda, bahkan anak-anak karena adanya perubahan pola ekonomi yang bertumpu pada upah tunai. Pada pekerja perempuan juga terdapat kekhawatiran akan masa depan mereka, karena keseluruhan hidupnya seolah-olah sudah habis untuk bekerja;

e. kehidupan rumah tangga (domestik) menjadi tidak harmonis, karena perempuan sudah letih bekerja di pabrik sehingga tidak dapat mengurus keluarga dengan lebih baik dan leluasa. 
Meningkatnya volume pekerjaan akibat industrialisasi ini diiringi dengan fenomena banyaknya pekerja dan buruh perempuan yang mengalami sakit sehingga absen dari pekerjaan atau tidak dapat masuk dan bekerja di pabrik. Banyak perempuan yang bekerja ini ternyata kembali melakukan shift kedua ketika pulang kembali ke rumah dalam bentuk kegiatan domestik, seperti memasak, membersihkan rumah, dan merawat anak. Hal ini menggambarkan bahwa perempuan tetap bekerja walaupun sudah pulang ke rumah sehingga dirasa perempuan memiliki waktu beristirahat yang lebih sedikit. Beberapa studi telah dilakukan untuk mengungkap apakah ada hubungan yang berarti antara 'pekerjaan tambahan' atau 'pekerjaan kedua' yang dilakukan perempuan-perempuan ini dengan kondisi kebugaran atau kesehatan. Namun, tetap tidak ditemukan hubungan yang benarbenar pasti bahwa kedua pekerjaan yang dilakukan oleh perempuan tersebut menyebabkan kelelahan dan mempengaruhi kesehatan mereka (Bratberg dkk., 2002).

Peran perempuan pada revolusi industri ini menggambarkan bahwa perempuan sebenarnya sudah sejak lama terjun di bidang bisnis dan ekonomi, sesuai yang diuraikan oleh Pincbeck (2019), sebagai berikut:"... cause some astonishment at the present day when it is so often wrongly assumed that women have only just begun to enter the business world."

Argumen tersebut menjadi landasan para pemikir feminis yang memperjuangkan kesetaraan perempuan. Peran perempuan sebagai penggerak roda ekonomi domestik sudah lama dijalani dengan mendapatkan penghasilan uang dari upah yang diterimanya. Selain itu, perempuan pekerja di ranah industri juga secara tidak langsung mendukung argumentasi bahwa perempuan sudah sejak lama menggerakkan ekonomi negara melalui perannya sebagai buruh pabrik yang menghasilkan barang-barang bernilai ekonomi. Secara singkat, argumentasi di atas menimbulkan suatu ungkapan bahwa sejarah ekonomi yang melupakan peran perempuan adalah pembahasan sejarah ekonomi yang tidak komprehensif. 
Adanya dua hal peran atau tugas yang berbeda tersebut mendorong pekerja perempuan dan menginspirasi para pemikir untuk memperjuangkan kesetaraan perempuan. Kesetaraan yang diperjuangkan pertama kali adalah kesetaraan upah. Selain itu, fenomena ini juga memicu beberapa hal lain seperti dikotomi dan separasi pekerjaan publik dan domestik hingga program pembatasan kelahiran, sebab adanya anggapan bahwa semakin banyak anak dapat mengurangi kinerja perempuan saat mengerjakan perannya sebagai pekerja. Meskipun itu, tidak ada hubungan yang benar-benar pasti juga yang mendukung argumen tersebut, sebab baik jumlah anak tidak berpengaruh signifikan terhadap performa pekerja perempuan, kesehatan, dan tingkat kematian perempuan (Weatherall dkk, 1994).

Definisi peran ganda perempuan, terkait dengan uraian sebelumya, meliputi dua hal yaitu, work dan care (Hervey \& Shaw, 1998). Definisi work diartikan sebagai peran perempuan dalam sebuah pekerjaan, seperti pada pekerjaan kantor dan pabrik. Hal ini mengandung makna bahwa pekerjaan yang dimaksud dilakukan di luar rumah. Sementara itu, istilah care merujuk pada peran perempuan pada posisi pengasuh anak atau keturunannya. Istilah ini kemudian berkembang menjadi segala peran perempuan di lingkungan keluarganya atau ranah domestik. Hal ini meliputi peran seorang perempuan sebagai istri bagi suaminya dan ibu bagi anak-anaknya. Dari pengertian ini dapat ditarik benang merah bahwa peran ganda pada intinya adalah dua peran yang dijalankan dalam waktu yang bersamaan. Dengan kata lain, peran ganda meliputi perempuan yang memiliki pekerjaan di luar rumah yang dijalani bersamaan dengan peran tradisional seorang perempuan sebagai istri dan ibu dalam keluarga, seperti menjadi mitra suami dalam membina rumah tangga, menyediakan kebutuhan rumah tangga, serta mengasuh dan mendidik anak-anak (Suryadi, 2004).

Peran ganda merupakan salah satu bentuk diskriminasi, karena peran kegiatan diemban lebih banyak oleh salah satu jenis kelamin. Peran ganda diartikan sebagai suatu penerapan peranan pada wilayah domestik dan wilayah publik. Atau secara umum 
peran ganda perempuan dapat diartikan perempuan yang menjalankan dua atau lebih peran dalam waktu yang bersamaan. Peran sebagai istri, seorang istri dituntut untuk mengetahui jalan pikiran suami dengan menjadi pendengar yang baik, dan melayani kebutuhan keluarga. Dapat dikatakan bahwa peran domestik adalah peran perempuan dalam keluarganya. Sementara itu, peran publik adalah peran perempuan sebagai tenaga kerja, anggota masyarakat, dan organisasi masyarakat. Keterlibatan wanita di luar rumah menandakan perempuan berusaha untuk mengubah sejarah hidup dengan membuat identitas baru dengan tidak hanya menjadi seorang ibu atau istri, tetapi juga sebagai seorang pekerja (Radhitya, 2018).

Perempuan selama ini tidak memiliki akses menuju sektor publik, seperti memiliki pekerjaan dan sejenisnya. Namun anggapan tersebut tidak sepenuhnya berlaku saat ini, sebab banyak alasan-alasan yang sudah mulai dapat diterima oleh masyarakat ketika perempuan memiliki profesi atau bekerja, seperti ingin mandiri, memanfaatkan pendidikan tinggi, memiliki skill yang dibutuhkan dalam dunia kerja, atau bahkan tuntutan tingkat sosial ekonomi keluarga yang tidak mencukupi. Perempuan tidak hanya melakukan tugas domestiknya, melainkan sudah banyak yang muncul dalam sektor publik untuk bekerja dengan harapan mampu memenuhi kebutuhan rumah tangga.

Hal ini juga dilakukan oleh perempuan Jawa yang berani mendobrak berbagai stigma tersebut, yang memutuskan untuk bekerja sebagai buruh gendong di beberapa pasar tradisonal di Daerah Istimewa Yogyakarta. Sebagian dari buruh gendong percaya bahwa untuk memenuhi kebutuhan keluarga adalah tanggungjawab setiap orang yang ada dalam keluarga tersebut: laki-laki atau perempuan dinilai sama. Perempuan boleh bekerja, walaupun, tetap harus memprioritaskan tugasnya sebagai seorang istri bagi suaminya dan sebagai ibu bagi anak-anaknya.

Dualisme (persamaan) karir terjadi bila suami maupun istri sama-sama bekerja dan mengurus rumah tangga secara bersama pula. Di dalam hubungannya dengan posisi masing-masing, setiap 
pasangan suami istri memiliki cara yang berbeda di dalam mengatur peranannya dalam pekerjaan dan rumah tangga. Wanita yang bekerja secara paruh waktu umumnya menganggap bahwa pekerjaan hanyalah sekedar hobi dan hanya menduduki prioritas kedua di bawah kepentingan keluarga. Dalam keluarga dualisme karir egalitarian, suami-istri bekerja tidak hanya sekedar mencari nafkah tetapi juga dalam persaingan untuk mendapatkan posisi yang sama dalam pengambilan keputusan serta berbagai aktivitas dalam keluarga.

Pada konteks Revolusi Industri, peran ganda perempuan pekerja pabrik dapat dianggap sebagai keuntungan karena perempuan pekerja dapat menghasilkan pendapatan untuk menghidupi keluarganya. Namun, tidak terdapat kesetaraan yang adil bagi pekerja perempuan, misal dari segi upah dan kondisi kerja sehingga banyak perempuan pekerja yang terpuruk kondisi kesehatan fisik dan mentalnya. Uraian ini secara umum berlaku pada perempuan pekerja yang tergolong pada strata ekonomi miskin.

Hal yang berbeda apabila membahas peran ganda perempuan yang bekerja pada pekerjaan yang berposisi tinggi, yang bukan sebagai pekerja kasar atau buruh. Perempuan yang bekerja pada posisi yang tinggi mendapatkan remunerasi yang lebih baik. Selain itu, apabila peran ganda perempuan ini tidak lagi dijalani, maka perempuan mendapatkan keuntungan karena terlepas dari beban pekerjaan dan mencari nafkah untuk keluarga. Perempuanperempuan ini secara umum akan memiliki waktu senggang yang lebih banyak untuk mengurus kegiatan atau kepentingan domestik. Hal ini menjadi suatu trade-off karena perempuan yang tidak lagi bekerja tidak lagi memiliki kebebasan secara ekonomi karena tidak lagi mendapatkan upah/gaji (Pinchbeck, 1930).

Peran ganda menjadi persoalan jika peran dalam rumah tangga tidak dibagi seimbang sehingga menimbulkan konflik. Secara pengertian konflik adalah suatu proses yang dimulai apabila salah satu pihak merasakan bahwa pihak lain telah atau akan mempengaruhi pihak lain. Pengertian konflik dapat juga dikatakan 
sebagai kondisi yang dipersepsikan oleh dua pihak yang merasakan ketidaksesuaian antara tujuan dan peluang untuk pencapaian tujuan. Konflik peran ganda terjadi jika adanya tekanan dari dua atau lebih peran yang diharapkan, dapat juga konflik terjadi karena dalam pemenuhan satu peran bertentangan dengan peran yang lain. Konflik peran lebih banyak bersifat psikologis, antara lain: rasa bersalah karena tidak dapat melakukan peran secara maksimal, kegelisahan, dan frustasi karena tuntutan peran pekerjaan dalam lingkungan kerja maupun rumah tangga yang menghabiskan tenaga (Utaminingsih, 2017).

Hakikatnya permasalahan peran ganda perempuan bukan pada peran yang dijalani tersebut, melainkan akibat atau dampak yang ditimbulkan dari peran ganda tersebut, yaitu beban ganda yang harus dipikul perempuan atau ibu dalam kehidupan berkeluarga. Pengertian beban ganda (double burden) adalah beban pekerjaan yang lebih banyak diterima oleh salah satu jenis kelamin daripada jenis kelamin lainnya. Rantai beban ganda tersebut tidak akan hilang dari perempuan, karena beban domestik perempuan satu dilimpahkan kepada pekerja rumah tangga yang mayoritas adalah perempuan. Hal yang menjadi tuntutan dalam persoalan peran ganda adalah peran pekerjaan rumah tangga tidak dilimpahkan pada satu orang saja, yaitu perempuan. Hal ini dapat diatasi apabila seluruh anggota keluarga tanpa membedakan jenis kelamin mau berbagi tugas sehingga dapat saling menggantikan.

\section{Buruh Gendong Sebagai Perempuan Jawa}

Pengertian buruh adalah orang yang bekerja untuk orang lain dengan mendapat upah. Buruh merupakan profesi yang bersifat relatif permanen dan stabil. Profesi sebagai buruh dikerjakan dalam jangka panjang sebagai pekerjaan utama bukan sebagai batu loncatan untuk mendapatkan perkerjaan yang lebih baik untuk masa yang akan datang. Buruh berbeda dengan pekerja. Pekerja adalah orang yang bekerja di suatu badan usaha milik swasta maupun milik pemerintah yang imbalannya berupa gaji sesuai 
peraturan perundang-undanganan yang berlaku. Gaji biasa diberikan mingguan dan bulanan. Sebaliknya, buruh adalah orang yang bekerja pada usaha perorangan yang imbalannya berupa upah dan biasa diberikan secara harian. Sistem kerja biasanya dilakukan secara harian dan borongan. Upah ditetapkan oleh kesepakatan bersama antara majikan dan buruh. Perempuan buruh gendong tidak memiliki keterampilan khusus dan tingkat pendidikannya rendah, sehingga mereka mengalami kesulitan untuk mencari pekerjaan yang lebih baik. Mereka memutuskan untuk menekuni profesi sebagai buruh gendong untuk mendapatkan penghasilan untuk terus dapat memenuhi kebutuhan keluarga (Estri, 2016). Oleh karena itu, buruh gendong dapat dikategorikan sebagai buruh kasar.

Pengertian buruh gendong tidak bisa disamakan dengan istilah buruh lainnya. Buruh gendong tidak sama dengan buruhburuh yang lain, seperti: buruh bangunan, buruh pabrik ataupun buruh tani. Meskipun pekerjaannya hampir sama, yaitu memberikan pelayanan jasa untuk mengangkut atau menggendongkan barang untuk orang lain, namun, sebutan untuk laki-laki berbeda dengan perempuan. Bagi laki-laki biasa disebut dengan kuli, sedangkan bagi perempuan dikenal dengan sebutan buruh gendong. Buruh gendong dilihat secara harfiah adalah profesi menggendong barang yang dilakukan oleh seorang perempuan. Dengan kata lain, buruh gendong adalah sebutan untuk seorang perempuan yang menyandang selendang jarit lurik (kain yang bermotif lurik) dan ada pula yang menggendong srumbung di punggungnya. Ada pula yang cuma sekedar menggunakan jarit lurik saja untuk menggendong barang yang besar, sedangkan srumbung dipakai untuk membawa barang yang relatif kecil-kecil tetapi berjumlah banyak.

Buruh gendong merupakan jenis pekerjaan yang tergolong ke dalam sektor informal. Pekerjaan jenis ini biasanya tidak membutuhkan persyaratan khusus layaknya pekerjaan lainnya, dan biasanya orang-orang yang bekerja di sektor ini tidak memiliki penghasilan tetap. Pekerjaan yang berkaitan dengan fisik ini tentu 
tidak terlalu menjanjikan dibandingkan pekerjaan lainnya. Namun karena rendahnya keterampilan yang dimiliki menjadikan mereka harus memanfaatkan peluang semaksimal mungkin guna mendapatkan penghasilan. Mereka harus berkeliling pasar untuk menawar jasa mengangkut barang-barang pembeli. Jika dibandingkan dengan berbagai jenis pekerjaan lainnya, upah seorang buruh gendong perempuan masih ternilai sangat murah, mereka hanya dibandrol sekitar Rp 3000,- setiap kali mengangkut barang. Belum adanya ketegasan dari pemerintah untuk menetapkan upah minimum yang harus dibayar setiap kali mengangkut barang menjadi kesulitan tersendiri bagi para buruh gendong. Hal ini membuat sering terjadinya ketidakseimbangan antara beban yang diangkut dengan upah yang diterima. Namun atas berbagai pertimbangan, mereka selalu merasa bahwa profesi sebagai buruh gendong di pasar-pasar tradisional dapat dijadikan sebagai alternatif di tengah-tengah kompleksnya tuntutan kehidupan yang harus dipenuhi. Pekerjaan ini juga tidak terikat dengan waktu, sebagian dari mereka ada yang berangkat dini hari, dan kembali ke rumah masing-masing saat sore hari. Begitu pun sebaliknya, bahkan terkadang mereka memutuskan untuk tidak kembali ke rumah dan beristirahat di emperan toko-toko sepanjang pasar.

Keberadaan buruh gendong di Yogyakarta telah ada sejak sebelum era kemerdekaan. Sebagian besar dari buruh gendong bekerja di Pasar Beringharjo, Pasar Induk Giwangan, dan Pasar Kranggan. Para buruh gendong tersebut berasal dari daerah pinggiran wilayah kota Yogyakarta yaitu desa-desa daerah Bantul, Kulonprogo, Gunung Kidul dan Sleman. Latar belakang kehidupan buruh gendong mayoritas berasal dari keluarga menengah ke bawah.

Dorongan menjadi seorang buruh gendong berawal dari ajakan teman sendiri maupun saudara. Sebagian besar buruh gendong sudah mulai menekuni profesi tersebut sejak remaja, bahkan ada yang sudah dikenalkan dengan profesi ini sejak masih kecil. Mereka didorong oleh berbagai faktor seperti lemahnya 
ekonomi keluarga, tingkat pendidikan yang rendah, dan kurangnya keterampilan yang dimiliki. Sebelum menggeluti dunia buruh gendong, sebagian dari mereka pernah mencoba menggeluti profesi lain, misal sebagai petani. Namun, mereka menilai bahwa bekerja sebagai petani akan memakan waktu yang lama untuk mendapatkan penghasilan setelah menjual hasil panen. Selain itu, jarang dari mereka yang memiliki lahan sendiri untuk dikerjakan dan hanya menjadi buruh tani untuk menggarap lahan milik orang lain. Apabila ingin membuka usaha, mereka terkendala oleh modal dan bahkan takut menanggung resiko kerugian. Mereka bertekad untuk menjadi buruh gendong dikarenakan keterbatasan lapangan pekerjaan dan tidak memiliki keahlian lain.

Buruh gendong bekerja dengan etos kerja yang tinggi. Hal tersebut terlihat dari cara menggendong dan mencari barang dagangan dari pelanggan maupun konsumen secara cepat, cekatan, kerjasama, hati-hati, dan rapi. Upaya tersebut untuk menunjukan pada konsumennya dengan memberikan pelayanan jasa sebaik mungkin agar pelanggan tetap memakai jasa mereka. Mereka bekerja dengan kompak, saling toleransi, dan memandang pekerjaan mereka sebagai sarana hiburan karena bertemu temanteman sepekerjaan. Permasalahan yang biasa terjadi di lingkungan kerja adalah persaingan antar buruh gendong. Meskipun tidak sampai menimbulkan masalah serius, tetapi dapat menurunkan semangat buruh gendong dalam bekerja. Walaupun demikian, bagi buruh gendong bekerja adalah bagian dari harga diri dan harus ikhlas menjalani. Mereka katakan lagi dengan bekerja mereka memiliki status, bisa menolong orang lain dan membahagiakan keluarga (Kalimah, 2014).

Pada budaya Jawa, banyak istilah-istilah yang mendudukkan posisi perempuan lebih rendah daripada laki-laki. Dan istilahistilah itu sudah tertanam dalam dalam hati masyarakat, sehingga dimaklumi dan diterima begitu saja. Seperti contoh dalam istilah Jawa ada menyebutkan bahwa istri sebagai kanca wingking, artinya teman belakang, sebagai teman dalam mengelola urusan rumah tangga, khususnya urusan anak, memasak, mencuci dan lain-lain. 
Ada lagi istilah lain suwarga nunut, neraka katut. Istilah itu juga diperuntukkan bagi para istri, bahwa suami adalah yang menentukan istri akan masuk surga atau neraka. Kalau suami masuk surga, berarti istri juga akan masuk surga, tetapi kalau suami masuk neraka, walaupun istri berhak untuk masuk surga karena amal perbuatan yang baik, tetapi tidak berhak bagi istri untuk masuk surga karena harus katut atau mengikuti suami masuk neraka (Hermawati, 2007).

Citra, peran dan status sebagai perempuan, telah diciptakan oleh budaya. Citra bagi seorang perempuan seperti yang diidealkan oleh budaya, antara lain, lemah lembut, penurut, tidak membantah, tidak boleh 'melebihi' laki-laki. Peran yang diidealkan seperti pengelola rumah tangga, sebagai pendukung karir suami, istri yang penurut dan ibu yang mrantasi. Citra yang dibuat untuk laki-laki antara lain, 'serba tahu', sebagai panutan harus 'lebih' dari perempuan, rasional, agresif. Peran laki-laki yang ideal adalah sebagai pencari nafkah keluarga, pelindung, dan mengayomi, sementara status idealnya adalah kepala keluarga (Raharjo, 1995).

Pada pengertian lain wanita diartikan seorang yang berani menderita bahkan untuk orang lain. Tetapi pada penelitian ini sepaham tidak menggunakan istilah wanita tetapi perempuan karena perempuan memiliki arti empu atau guru yang bermakna dihargai dan dihormati dalam apapun perannya. Karakter perempuan Jawa sangat identik dengan kultur budaya Jawa bertutur halus, tenang, tidak suka konflik menjunjung nilai keluarga, daya tahan menderita yang tinggi dan dapat memegang peranan penting dalam perekonomian keluarga. Kemampuan seorang perempuan Jawa sebagai istri dikatakan sebagai cancut tali wanda yang artinya suatu konsep Jawa yang menggambarkan sikap untuk terlibat, mengambil peran bahkan komando, dan taktis untuk menghadapi masalah tidak hanya dalam ide dan pengambil keputusan mengenai langkah-langkah apa yang akan ditempuh tetapi juga dalam pelaksanaan (Handayani \& Novianto, 2004).

Padangan buruh gendong melihat pengaruh kontruksi budaya dalam membentuk karakter perempuan Jawa membentuk 
deskripsi yang bermacam-macam. Menurut buruh gendong, perempuan Jawa berhati halus dan keibuan. Akan tetapi, juga tangguh dan bertanggung jawab atas peran serta keadaan yang sedang dihadapi. Perempuan Jawa akan berusaha keras dalam kondisi darurat seperti persoalan makan. Mampu bertahan hidup meskipun dalam kondisi tidak punya uang. Saat ekonomi keluarga tidak stabil maka perempuan Jawa akan keluar dari rumahnya untuk mencukupi kebutuhan sehari-hari menyenangkan anak dan keluarga serta mengusahakan agar anak selalu bahagia. Perempuan Jawa dalam hubungan antar personal, ketika sudah bersuami harus menuruti keinginan suami apapun perintah suami. Perempuan Jawa harus menuruti selagi itu tidak bertentangan dengan kondisi yang tengah dihadapi dan mengurusi keluarga.

Bekerja sebagai buruh gendong adalah peran perempuan sebagai bentuk kerelaan dan toleransi antar keluarga dengan tujuan gotong royong membangun kehidupan yang lebih baik. Meskipun perempuan Jawa erat dengan pekerjaan domestik, perempuan Jawa tetap memiliki rasa 'sungkan' yang tinggi untuk meminta uang lebih kepada suami. Hal tersebut menyebabkan perempuan Jawa akhirnya memutuskan untuk pergi dan bekerja di luar rumah supaya tercipta keselarasan hidup yang lebih baik. Pandangan buruh gendong terhadap perempuan Jawa adalah sosok yang mampu menyeimbangkan antara tuntutan kehidupan rumah tangga dan pekerjaan serta mampu membangun hubungan antar personal anggota keluarga berlandaskan saling kerjasama.

\section{Peran Ganda Yang Dijalani Buruh Gendong}

Profil buruh gendong di pasar Giwangan, Beringharjo dan Kranggan memiliki rentang usia 43 hingga 75 tahun. Beberapa di antara mereka berstatus janda dan beberapa lainnya masih berstatus menikah dengan suami berpenghasilan rendah dan tidak tentu. Motivasi bekerja menjadi buruh gendong adalah dorongan untuk memenuhi kebutuhan ekonomi keluarga baik sebagai tulang punggung keluarga ataupun sekedar membantu memenuhi 
kebutuhan keluarga dan biaya pendidikan anak. Pada umumnya mereka, sudah mulai menekuni profesi buruh gendong sejak remaja, bahkan ada yang sudah dikenalkan dengan profesi ini sejak masih kecil, karena didorong oleh berbagai faktor, seperti ekonomi, pendidikan, dan rendahnya keterampilan yang dimilikinya. Pekerjaan yang berkaitan erat dengan fisik ini tidak sepenuhnya mampu memenuhi kebutuhan mereka, namun karena rendahnya keterampilan yang dimiliki menjadikan buruh gendong sebagai solusi mutlak dalam memenuhi berbagai kebutuhan hidup. Walaupun sebelumnya, beberapa di antara mereka pernah menggeluti pekerjaan sebagai petani. Namun, mereka menilai bahwa bekerja sebagai petani akan memakan waktu yang lama sebelum panen sehingga, ketika ada kebutuhan mendesak tidak dapat memenuhi.

Bermula dari kecemasan karena kebutuhan hidup semakin tinggi sehingga takut tidak mampu memenuhinya maka mereka memilih bekerja sebagi buruh gendong. Tujuannya untuk mendapatkan tambahan biaya hidup. Akan tetapi, yang terjadi dalam pemenuhan kebutuhan rumah tangga, buruh gendong menjadi tulang punggung keluarga. Penghasilan mereka sebagai buruh gendong bisa dikatakan mencukupi meskipun dengan segala keterbatasan dan dengan berbagai strategi mengatur uang. Melalui perannya bekerja, buruh gendong mampu memberikan kontribusi untuk membebaskan keluarga dari masalah ekonomi.

Dampak dari peran ganda yang dijalani buruh gendong adalah:

\section{Diskriminasi upah}

Buruh gendong tentu tidak memiliki pendapatan yang pasti, namun, mereka selalu berusaha untuk mendapatkan pelanggan. Hal ini menimbulkan perebutan pelanggan antar sesama mereka. Buruh gendong perempuan juga merasa adanya perlakuan diskriminasi oleh buruh gendong laki-laki dalam beberapa hal. Pertama, buruh gendong laki-laki langsung membongkar muatan dari kendaraan transportasi pedagang, sehingga memiliki akses 
kesempatan yang lebih besar untuk mengangkut barang dalam jumlah yang lebih banyak. Hal ini cenderung akan menimbulkan jumlah pendapatan buruh laki-laki yang lebih banyak, sebab mereka dapat mengangkut barang lebih banyak. Kedua, buruh lakilaki dibayar dengan upah yang lebih besar. Berbeda dengan buruh perempuan yang harus keliling pasar untuk mendapatkan pelanggan dan itupun dibayar dengan upah yang rendah. Biasanya dalam sekali angkat buruh gendong laki-laki mendapatkan upah sebesar Rp 5000,-. Sementara itu, buruh gendong perempuan hanya diberi upah sebesar Rp 3000,- meskipun beban yang mereka angkat mempunyai kapasitas yang sama. Pelanggan yang ada di dalam pasar pun biasanya juga cenderung memilih buruh gendong lakilaki dibandingkan perempuan, karena perempuan dinilai lambat dalam mengangkut barang.

\section{Adanya keluhan kesehatan}

Buruh gendong sering mengalami masalah dan keluhan fisik dan penyakit degeneratif, seperti tekanan darah tinggi (hipertensi). Hal ini sangat beralasan mengingat umumnya buruh gendong yang rata-rata berusia 40 hingga 75 tahun. Selain itu, kekuatan ekonomi atau pendapatan dari buruh gendong ini juga membatasi kemampuan untuk mendapatkan makanan atau asupan gizi yang lebih baik. Umumnya, buruh gendong yang berpendapatan rendah mengkonsumsi makanan dengan tujuan agar kenyang dan kembali bertenaga untuk bekerja esok harinya. Hal ini memperburuk status kesehatan buruh gendong yang umumnya sudah berusia lanjut. Keluhan kesehatan lain adalah timbulnya berbagai keluhan rasa nyeri dan sakit di bagian tubuh mereka, seperti di bahu, punggung, pinggang dan kaki, sebab umumnya mereka mengangkat beban mulai dari $15 \mathrm{~kg}$ hingga $90 \mathrm{~kg}$.

Masalah kesehatan tersebut belum sepenuhnya dapat diatasi meskipun sudah diupayakan untuk ditanggulangi oleh Yayasan Yasanti yang menaungi dan melindungi mereka serta pemerintah daerah melalui program pelayanan kesehatan gratis. Bagi yang memiliki kartu asuransi kesehatan beruntung dapat berobat dengan 
gratis. Namun sebaliknya, bagi yang tidak memiliki penjaminan Kesehatan, maka mau tidak mau harus berobat sendiri.

\section{Tekanan psikis}

Tekanan psikis berupa ketakutan akan tidak terpenuhinya ekonomi di rumah tangga. Konflik peran ganda muncul apabila perempuan merasakan ketegangan antara peran pekerjaan, peran keluarga, serta peran sosialnya yang berdampak pada kelelahan secara psikis pada diri perempuan. Adapula peran di masyarakat, di samping peran menjalani pekerjaan rumah tangga dan pekerjaan sebagai buruh gendong. Peran dalam masyarakat, antara lain, adalah menghadiri undangan hajatan, melayat dan kegiatan masyarakat lain. Peran perempuan di tingkat komunitas atau masyarakat ini juga tidak jarang mengharuskan adanya kekuatan ekonomi di baliknya. Pada komunitas atau masyarakat di Yogyakarta, umumnya perempuan melakukan kegiatan ekonomi yang bersifat sosial, yaitu memberikan sumbangan dalam bentuk uang saat menghadari hajatan atau melayat.

Ketika perempuan menjalankan dua atau lebih peran sekaligus, maka mereka akan merasa takut ketika salah satu peran yang dijalankan tidak sesuai dengan harapan-harapan dari pihakpihak yang terlibat di dalamnya. Sebagai ibu rumah tangga dalam menjalankan perannya, perempuan merasa khawatir dan takut jika keluarganya merasa kurang puas dengan peran keluarga yang telah dijalankannya. Selain itu, terdapat pula ketakutan yang berasal dari permasalahan yang dihadapinya di tempat ia bekerja. Selain hal tersebut, sebagai ibu perempuan juga merasa sangat bertanggung jawab atas urusan anak (Bimono, 2017). Pada buruh gendong kecemasan dan ketakutan terjadi jika mereka tidak dapat membahagiakan anak-anak mereka. Kecemasan juga timbal apabila tidak dapat memenuhi kebutuhan ekonomi rumah tangga jika jasa mereka sedang sepi karena persaingan antar buruh.

\section{Waktu bersama keluarga menjadi kurang}

Para buruh gendong mengawali hari langsung pergi ke pasar, jika pasar dibuka di pagi hari, seperti pasar Beringharjo. Beberapa 
dari mereka ada yang menginap di pinggir-pinggir toko misalnya di Pasar Beringharjo. Sebagian lagi ada yang indekos di sekitar pasar Giwangan dan pulang tiga kali dalam seminggu. Buruh gendong yang melaju, yaitu yang tinggal di luar daerah yang berbeda dari pasar tempat mereka bekerja, maka mereka harus berangkat pagi-pagi naik kendaraan umum, ojek, motor ataupun sepeda. Di pasar mereka akan melakukan pekerjaannya sebagai buruh gendong. Sore hari mereka pulang ke rumah melakukan aktifitas rumah tangga. Di malam hari waktu digunakan untuk bercengkrama dengan keluarga, anak dan cucu mereka. Tidak semua buruh gendong pulang ke rumah mereka masing-masing. Dampak yang terjadi adalah waktu bersama keluarga menjadi berkurang. Keterbatasan waktu tersebut disebabkan waktu kerja buruh gendong yang tidak menentu. Selain itu, hambatan jarak antara pasar dan rumah juga menjadi penghalang untuk beberapa buruh untuk bersama keluarga, seperti pada buruh yang harus indekos di dekat pasar tempat mereka bekerja.

\section{SIMPULAN}

Penelitian ini menyimpulkan bahwa buruh gendong memiliki karakter perempuan Jawa yang tidak selalu menjadi konco wingking saja dengan sifat feminin yang identik dengan suku Jawa. Buruh gendong justru merepresentasikan bahwa perempuan Jawa adalah seorang yang tidak hanya halus dan keibuan, tetapi juga tangguh, berani dan kuat dalam keadaan sulit. Perempuan Jawa dalam hubungan antar personal adalah sosok yang mampu menyeimbangkan antara tuntutan kehidupan rumah tangga dan pekerjaan. Perempuan Jawa yang sudah bersuami harus menuruti keinginan suami selama tidak bertentangan dengan kondisi yang dihadapi dan norma-norma keluarga. Hal ini mengimplikasikan bahwa peran ganda tidak dirasakan sebagai beban, melainkan peran ganda tersebut akan dijalani dengan kerelaan sebagai bentuk kontribusi perempuan tersebut untuk keluarganya. Selanjutnya, permasalahan peran ganda perempuan tidak terletak pada peran yang dijalani, melainkan pada akibat atau dampak yang 
ditimbulkan, yang dapat diatasi dengan mengatur dan membagi peran dan waktu dengan sebaik-baiknya dan seimbang antar anggota keluarga. Maka dengan demikian ketidakadilan peran tidak terjadi.

\section{DAFTAR PUSTAKA}

Bakker, A., \& Zubair, A. C. (1990). Metode Penelitian Filsafat. Yogyakarta: Kanisius.

Bimono, A. (2017). "Peran Ganda Perempuan Pedagang di Pasar Beringharjo Yogyakarta" dalam Skripsi Fakultas Ilmu Sosial, Universitas Negeri Yogyakarta.

Bratberg, E., Dahl, S. Å., \& Risa, A. E. (2002). 'The double burden': do combinations of career and family obligations increase sickness absence among women?. European Sociological Review, 18(2), 233-249.

Estri, B. (2016). "Peran Perempuan Buruh Gendong di Kota Yogyakarta" dalam Skripsi Departemen Ilmu Ekonomi Fakultas Ekonomi, Universitas Muhamadiyah Yogyakarta.

Fakih, M. (2016). Analisis Gender dan Transformasi Sosial. Yogyakarta: Insist Press.

Handayani, C. S., \& Adrian, N. (2004). Kuasa Wanita Jawa. Yogyakarta: LKis Pelangi Aksara.

Hermawati, T. (2007). Budaya Jawa dan Kesetaraan Gender dalam Jurnal Komunikasi Massa, 1(1), 18-24.

Hervey, T., \& Shaw, J. (1998). Women, work and care: Women's dual role and double burden in EC sex equality law. Journal of European Social Policy, 8(1), 43-63.

Hidayah, N. (2009). Eksistensi Buruh Gendong Sebagai Pilihan Pekerjaan di Sektor Informal (Studi Kasus di Pasar Giwangan, Yogyakarta). Dimensia, 3(1), 19.

Istiatun. (2014). "Profil Prempuan Buruh Gendong di Pasar Beringharjo Kota Yogyakarta" dalam Tesis Program Studi Sosiologi Minat Studi Pembangun, Universitas Gadjah Mada.

Kalimah, S. (2014). "Kontribusi Buruh Gendong Perempuan di Pasar Giwangan Yogyakarta Terhadap Ketahanan Keluarga" dalam 
Skripsi Fakultas Ilmu Pendidikan, Universitas Negeri Yogyakarta. Pinchbeck, I. (1930). Women Workers and the Industrial Revolution, 1750-1850. London: George Routledge.

Prahara, S. A. (2010). "Makna Kerja Buruh Gendong Perempuan di Pasar Beringharjo Yogyakarta: Sebuah Studi Fenomenologi" dalam Tesis Magister Sains Psikologi Fakultas Psikologi, Universitas Gadjah Mada.

Radhitya, T. V. (2018). Peran Ganda Yang Dialami Pekerja K3L Universitas Padjajaran. Focus: Jurnal Pekerjaan Sosial, 1(3), 204219.

Raharjo, Y. (1995). Gender dan Pembangunan. Jakarta: Puslitbang Kependudukan dan Ketenagakerjaan, LIPI (PPT-LIPI).

Reese, L. (2019). The Plight of Women's Work in the Early Industrial Revolution in England and Wales. Diakses 08 September 2020. http://www.womeninworldhistory.com/ lesson7.html

Suryadi, D. (2001). "Gambaran Konflik dan Reaksi Emosional Perempuan Dalam Menentukan Prioritas Peran Gandanya" dalam Skripsi Fakultas Psikologi Universitas Tarumanegara.

Utaminingsih, A. (2017). Gender dan Perempuan Karir. Malang: UB Press.

Uyun, Q. (2002). Peran Gender dalam Budaya Jawa. Psikologika, $7(13), 32-42$.

Weatherall, R., Joshi, H., \& Macran, S. (1994). Double burden or double blessing? Employment, motherhood and mortality in the longitudinal study of England and Wales. Social Science $\mathcal{E}$ Medicine 38(2): 285-297. 